\title{
The resurrection of Jesus: What's left to say?
}

\author{
P J W (Flip) Schutte (Witbank) ${ }^{1}$ \\ Research Associate: Department of New Testament Studies \\ University of Pretoria
}

\begin{abstract}
The resurrection of Jesus is one of the most discussed topics in the current theological debate. It divides the theologians involved into either liberal or orthodox. Those who enter the debate are labeled. The main issue centers around the arguments: historical or metaphorical? This article is a review of the 2004 publication by Stephen Patterson entitled "Beyond the passion: Rethinking the death and life of Jesus." John Dominic Crossan's and N T Wright's point of view, as summarized by Robert B Stewart in his 2006 publication "The resurrection of Jesus", is also part of the discussion.
\end{abstract}

\section{INTRODUCTION}

The interpretation of the narrative about Jesus' resurrection divided the theological seen in roughly two sides. On the one side are the so called liberals, and on the other side is the orthodox or maybe better known as the fundamentalists. Imagine the two sides as the two opposite ends of a line. Everybody who participates in the debate can be plotted somewhere on the line, either nearer to the middle or nearer to one of the ends. The disagreement is not about Jesus' death as a fact. Both sides of the current debate largely agree about the reality and circumstances of the crucifixion and, for that matter, of the importance of the resurrection for Christianity. But as there is disagreement within one side on these issues, the disagreement between the different sides of the debate is even larger.

Within the last few years, a few significant contributions have been made to the debate. This article serves as a review on the contribution of

\footnotetext{
${ }^{1} \mathrm{Dr} P \mathrm{~J}$ W Schutte (D Litt et Phil, DTh, PhD) participated as research associate in the project "Biblical Theology and Hermeneutics, directed by Dr Andries G van Aarde, Professor Emeritus, Faculty of Theology, University of Pretoria. This essay is a review article of two books, S J Patterson's (2006), Beyond the passion: Re-thinking the life and death of Jesus (Fortress) and R B Stewart (ed) (2006) The resurrection of Jesus: John Dominic Crossan and NT Wright in dialogue (Fortress).
} 
Stephen Patterson. The 2004 publication of Patterson with the title Beyond the passion with the subtitle Rethinking the death and life of Jesus will be reviewed. The book's theological reflection on Christ's death is set in the context of the John Dominic Crossan (see his 1998 publication: The birth of Christianity. Discovering what happened in the years immediately after the execution of Jesus.) and Marcus Borg (especially his 2002 publication: Reading the Bible again for the first time: Taking the Bible seriously but not literally.) strand of New Testament scholarship (on which Patterson plays his own variations). Patterson became involved with the Jesus Seminar in 1988, because he became convinced that the twentieth century Christianity was veering dangerously close to docetism, the idea that Jesus' historicity is not really important. He insists that it is very important. The idea that we have discovered who God is in a real person, in a human life and destiny is what connects Christian faith so closely to human life and experience. Several times he quotes, with approval, John Dominic Crossan's definition that Christian faith is always 1 ) an act of faith 2) in the historical Jesus 3) as the manifestation of God.

The 2006 publication of Robert B Stewart The resurrection of Jesus, is also relevant when it comes to this debate. This book was the result of the debate that was held on March, 11, 2005 in the Leavell Chapel on the campus of New Orleans Baptist Theological Seminary in front of nearly a thousand people. The topic of the debate was: "The resurrection: Historical event or theological explanation?" The participants in the debate were N T Wright and John Dominic Crossan. They are not on the same side!

This article will commence with an overview of the book of Patterson. Then a summary of the main arguments from the Wright-Crossan debate will be given. Hopefully this condensed synopsis will stimulate you, the reader to make your own preliminary conclusions, because in theology the conclusion is always only the premise for the next debate. When it comes to a topic such as the resurrection, the argumentation sometimes goes beyond the exegetical and the scientific. There is always an autobiographical dimension. The arguments touch the improvable arenas of the spiritual and the belief. In the conclusion I'll share my view with you.

\section{STEPHEN J PATTERSON}

During the past decade there has been a flood of books on the "historical Jesus." One might think that everything that could be said about Jesus had been said and more than once. Prior to the nineteenth century no one, including theologians, used the term "the historical Jesus." The term became current when biblical scholars made the distinction between the "historical 
Jesus" and the "Christ of faith," or to use Marcus Borg's (1987:4) helpful terms, "the pre-Easter Jesus" and the "post-Easter Jesus." The quest for the Jesus of history over the past century, using modern historical methods, has been an attempt to distinguish between what Jesus said and did (the historical Jesus) and what the early Church taught about him (the Christ of faith).

Stephen Patterson is Professor of New Testament at Eden Theological Seminary in St Louis, Missouri. Convinced that "one of the great mistakes of Christian theology has been our attempt to understand the death and resurrection of Jesus apart from his life" (Patterson 2004:2), he wrote his book to confront and challenge this separation. Evidence of the mistake is clear in the contemporary church when you hear, out of context, such phrases as "Christ died for you," and "Accept Christ as your personal Savior". He points out that the first followers of Jesus generally did not understand the death and resurrection apart from his life. In the four Gospels, the death/resurrection of Jesus is portrayed as the consequence of his life. In the concluding chapter of his book, the author laments that

... for most of us who assemble in the name of Jesus, he is dead. His words and deeds mean little to us, if anything at all. We do not look to Jesus for a way of life, but for salvation. "He died that we might live." Indeed. It seems we have to kill him in order that we might live whatever lives our power and privilege allow us to live. When real life is at stake, most of us will take personal salvation over the empire of God any day.

(Paterson 2004:30)

Countering the mistake of Christian theology, Patterson focuses on three early Christian understandings of the death of Jesus: as "Victim", as "Martyr", and as "Sacrifice". He writes, "I hope to show that these three strands, though distinct, work together to point the would-be followers of Jesus back to his life - to his words, his deeds, and his fate - as a life to be embraced as the life, and a fate to call one's own" (Patterson 2004:4). Using these three categories (victim, martyr and sacrifice), he marshals early Christian materials under each heading to support his argument, which points followers of Jesus, as he said, back to his life!

\subsection{Victim}

Stephen Patterson stresses that before we can deal with these responses to the death of Jesus we must be clear about who killed Jesus and why. When Jesus came into Galilee he announced that the empire of God was at hand. The established empire was The Pax Romana (Patterson 2004:15), 
maintained by violence. It was politically, economically and socially structured as a pyramid of patronage, the wealthy and powerful at the top and the poor and dispossessed at the bottom, held together by "loyalty, piety and Roman family values" (Patterson 2004:18). The empire of God, described and demonstrated by Jesus, was structured horizontally, as a "open table" where all people are equally welcome, including expendable people like fishermen, prostitutes, lepers, beggars, the sick and the disabled. Soon, the empire of God was seen as subversive of the empire of Caesar.

After several years of activity Jesus was charged with sedition against the Roman state and crucified in Jerusalem, probably around Passover, on order of Pontius Pilate, the Roman prefect. In the light of what Jesus had said and done and what he meant to them, the first followers of Jesus were impelled to find meaning in the fact that he was a victim of the empire. Reflecting on this understanding of Jesus, Patterson suggests that the death of Jesus as victim could hold meaning for us still, "if we have the courage to face it - and to face the consequences of realizing how inhospitable the world remains to Jesus' vision of God's empire" (Patterson 2004:37).

\subsection{Martyr}

The second response to the crucifixion by the early followers of Jesus was to understand him as Martyr, meaning "someone whose death in the face of great opposition becomes a witness to others" (Patterson 2004:39). Jewish history contained stories of heroes who, living under the tyranny of foreign rule, were faithful to God in spite of persecution and the threat of death. They were considered "God's suffering servants, God's righteous ones" (Patterson 2004:41). Also in the Hellenistic world, there were stories of those who died "nobly, with unflinching bravery and loyalty" for their principles (Patterson 2004:48). In this context, the early followers of Jesus saw that Jesus was not only a victim, but a martyr who "died willingly, nobly, for a cause" (Patterson 2004:52). Patterson traces the concept of Jesus as martyr in some of the letters of St Paul and in the Gospels according to Mark and John. There he finds the theme that "Jesus died for God's new empire, that new way of being in the world he tried to exemplify in his words and deeds" (Patterson 2004:67). $\mathrm{He}$ ends this section with this reflection:

To speak of Jesus as martyr is to consider the values, ideas, and principles he lived and died for, and the God who comes to life in them, and to ask what it would take to bring that God to life again in lives we might live. What would it cost to do this? Would it be worth it? Would it be worth everything?

(Patterson 2004:68). 


\subsection{Sacrifice}

The third response was to understand the death of Jesus as a sacrifice. Patterson deftly interprets the treatment of sacrifice in the letter to the Hebrews in the context of practices in the surrounding Roman world. He demonstrates in the process how Christians' affirmation of Christ's death as the sole sacrifice amounted to a powerful political statement, since in that culture sacrifice was understood as the very glue that held together the existing social structures. To attach such a view to Jesus' death was really to confirm the revolutionary practice of Jesus' life.

Pointing thus out that sacrifice is not a familiar metaphor in our culture he informs us that in the world of Christian origins, sacrifice was "ubiquitous" (Patterson 2004:82). In both Jewish and Hellenistic cities a sacrifice was a public event of the slaughtering of an animal as an offering to the gods and as a feast of meat which was a sign of "one's membership in a group, whether that be a family, a club, a city, or finally an empire" (Patterson 2004:73). Also in the Roman Empire, when faced with a military, political or economic crisis, sometimes a human being was sacrificed. It was believed that the person, usually destitute or socially marginal, would ritually bear away whatever had offended the gods. Then there was, occasionally, a "person's voluntary sacrifice on behalf of his or her people" (Patterson 2004:75). In the case of Jesus, he sacrificed himself in the cause of the empire of God.

He then explores (Patterson 2004:77) the understanding of "Jesus the Sacrifice" using the letters of St Paul and the Gospel of Mark as sources. He emphasizes that to speak of the death of Jesus as a sacrifice is to understand that his life was not taken from him, but offered voluntarily for the cause of the empire of God and in the hope that his death would create among his followers "a community who would be devoted to the same things to which Jesus devoted himself" (Patterson 2004:84).

\subsection{Epilogue}

In an Epilogue, Patterson (2004:104) points out that resurrection was a belief in many ancient religions and that many prophets, martyrs and heroes were believed to have been resurrected. Consequently, the proclamation that Jesus has been resurrected would not be unique. In Jewish tradition, to say that God had raised someone from the dead meant that because he was faithful to God unto death he was vindicated by God. The problem that the followers of Jesus had, was "believing that God would raise Jesus from the dead" (Patterson 2004:108). He was a victim, a martyr and had sacrificed his life, but "he was born a peasant and died a criminal" (Patterson 2004:110). He was a nobody. Patterson writes: "What is remarkable about the early Church resurrection 
proclamation was that it claimed Jesus had been raised from the dead Jesus, not Caesar" (Patterson 2004:112).

Stephen Patterson is convinced that the three ways of understanding the death of Jesus, as victim, martyr and sacrifice, were ways of calling attention to his life. Patterson (2004:127) writes: "His death mattered to them because his life had mattered to them. They spoke of his death in ways that affirmed his life, and reaffirmed their own commitment to the values and vision stamped into his life by his words and deeds."

This rethinking of the death and life of Jesus is a profound and audacious challenge to the contemporary church to hear once again the Good News of the vision of the empire of God which was "at hand" in the words and deeds of Jesus. Then perhaps, when "real life is at stake," we will embrace our commitment to follow him, taking the vision of the empire of God over salvation any day (Patterson 2004:130). The life that is at stake is the life of one who practices open table fellowship, who has a message of divine favour for the least and the outcast, and who gives the Romans and their puppets good reason to suspect that a peasant-worker awakening is under way.

His book contends thus that the real meaning of Jesus' death, for the first Christians and for us, is the challenge to live as he lived and taught. Jesus pointed a way to an alternative empire of God and demonstrated in his own life that you could live as though you already belonged to it. His death showed that you could follow that path through, without retreat, to the very end. Knowing Jesus had done it, his disciples had hope that they could too.

One of Patterson's prime objections to traditional doctrine is that it does not fit with the historical facts as he reconstructs them. Patterson is clear that Jesus' death is the work of an evil empire and that God had nothing to do with it. One of the most consistent criticisms of atonement theologies is that they portray a God who endorses violence (affirms penal suffering as the remedy for guilt) and practices it (God orchestrates Jesus' killers in the grand salvation plan).

Everything about Jesus makes only sense to Patterson when it is viewed in the light of his life, specifically when it comes to understand his followers' belief in his resurrection. The question can be asked: Is not the resurrection of Jesus something else? Is that not the type of event so powerful that nothing in his life could carry much significance after that? Then Patterson (2004:126) answers: "Not at all ... apart from Jesus' life the resurrection proclamation would never have been ventured in the first place."

Stephen Patterson does not take the Gospel accounts of the resurrection as historical, but he does imagine that people in the Jesus movement did indeed have the kind of spiritual experiences Paul and others 
came to understand as post resurrection manifestations of the risen Christ. The origin of Christian claims about the resurrection of Jesus was the conviction among his followers that he had been right about God. The first commitment of the early Christians was to Jesus, his message, his gospel. For latter-day Christians, that Jesus was right depends on whether the resurrection is a historical event. This shift is crucial, for it involves a shift in first commitments: from message to miracle, from gospel to power. Patterson considers what Jesus believed about God, about human community and about what gives life real meaning. He writes "Jesus experienced intimately a transcendent quality to experience that was more real, more satisfying, more hopeful than what life - even a successful life - can offer. It is this transcendent quality we call God. Its nature is love. That is what Jesus knew" (Patterson 1998:239).

The question then is: If it is not a historical event, why then did the followers of Jesus say that God had raised Jesus from the dead? Patterson (2004:127) answers the question by saying that they said it because they had faith in him and in his cause. To them Jesus was a martyr, not a victim, and resurrection is part of the martyr's story. It is the vindication part. The followers of Jesus believed that in his words were the Word of God and in his deeds he revealed the will of God. Resurrection was thus a way of proclaiming the significance of Jesus' life. His death matters to them, according to Patterson (2004:127) because his life mattered. In his life they came to know God.

The vision of the new empire that Jesus stood for was not killed by the cross! For Paul then (Patterson 2004:129) to experience the resurrection of Jesus was to become possessed by his Spirit, to share "the mind of Christ," and to embrace the life of Christ as his own. Paul and others formed communities that would be the "body of Christ," embodying the life of love and mutual care that Jesus had died for. What he died for, they would now, according to Patterson (2004:129) live for, until God would finally establish the empire of God as the universal rule of love and justice in the world.

So then, why did the followers of Jesus said that God had resurrected him? Patterson (2004:130) answers that they were responding to the compelling vision of Jesus, who lived on for them, alive in their midst. Jesus was really alive, spiritually present with them. To say today that Jesus was resurrected and that he lives, it must above all, according to Patterson (2004:131) mean that somehow he still offers us the vision of a new empire, into which we are still invited in a very real way.

Apart from his words and deeds, the living Jesus would have meant nothing to those who encountered him in the private and public places of antiquity. Neither can Jesus be alive to us apart from his 
words and deeds. He is alive to us only as he was alive to them, as a real invitation into a way of live we can see reflected in his own life, and the God to be encountered there.

(Patterson 2004:131)

Patterson points out that belief in resurrection or translation into heaven was not uncommon in the Hellenistic world, but the expectation was associated with emperors and the like. Jesus was a nobody, a visionary martyred for a cause. His followers believed in him and his cause. Since his cause was just, they believed a righteous God ought to raise him if he fell to his enemies. He deserved to be on the same plane with the Caesars (or higher). The scandalous thing about claiming resurrection for him was not that such a thing should happen at all, but that it should happen to this nobodies' somebody. The point was not that sins had been removed or that a dead person was alive: it was that Jesus' message was right. "This is why, when at last he was killed, they proclaimed his resurrection. They could have done this on the day he died, and probably did."

\subsection{Summary}

Stephen Patterson, in his argumentation of the topic, thus uses historical research to conclude that the resurrection must be interpreted metaphorically. Jesus did not die on a cross for the sins of the world. His life was not taken from him, but he offered it voluntarily for the cause of the empire of God. He was willing to die because he believed in the message of his own preaching. He was willing to die in the hope that his death would create among his followers a community who would be devoted to the same things to which he devoted himself (Patterson 2004:84). The followers of Jesus believed that in his words were the Word of God and in his deeds he revealed the will of God. Resurrection was thus a way of proclaiming the significance of Jesus' life. His death matters to them (2004:127) because his life mattered. In his life they came to know God. They claimed his resurrection as the vindication part of his martyrdom, not because it was a historical fact.

\section{N T WRIGHT}

Tom Wright has a different opinion and interpretation of the resurrection than the one held by Patterson that we took note of in the previous paragraph. On the line between a historical or metaphorical interpretation of the resurrection, Tom Wright is on the historical side. 
Tom Wright is the bishop of Durham. He has the fourth-highest position in the Church of England. He was previously canon theologian of Westminster Abbey and a former university instructor at Cambridge, Oxford, and McGill in Montreal. He enriched the resurrection debate with his 817-page publication The resurrection of the Son of God (Fortress Press). I could get hold of an extensive review written by Richard Ostling (2003) on the above mentioned book of Wright, which I will use to help summarize Wright's argument shortly. I will also use Stewart's publication (Robert Stewart published the CrossanWright dialogue in his 2006 publication: The resurrection of Jesus), and an article written by Wright in this Stewart-publication.

\subsection{Wright's argument}

Tom Wright starts his argument in his debate with Crossan on March, 11, 2005 in the Leavell Chapel on the campus of New Orleans Baptist Theological Seminary, by saying that one cannot separate the resurrection from early Christianity without distorting the Christian worldview (Stewart 2006:17). Earlier, Tom Wright (1998:118) wrote: "They reconstructed their worldview, their aims and agendas, around this belief so that it become, not merely an extra oddity, bolted onto the outside of the worldview they already had, but the transforming principle, the string that had pulled back the curtain, revealing God's future as having already arrived in the present." This worldview represents a startling, fresh mutation within second-Temple Judaism. Tom Wright (2006:18) summarizes this mutation within Judaism as follows:

First, belief in resurrection has moved from being a peripheral item of belief, as it is in Judaism, to the center ... Second, the meaning of resurrection has been sharpened up ... the body will be transformed into a new type of immortal physicality ... Third, there is no spectrum of belief in early Christianity on what happens after death ... But they all, except the Gnostics and the semi-Gnostics, believe in resurrection ... Fourth, resurrection as an event has split into two ... Christ the first fruits, and then at his coming, those who belong to Him ... Fifth, resurrection functions in a newly metaphorical way ... with reference to baptism and holiness. Sixth, ... they made the resurrection a key element in their demonstration that he was the Messiah.

For Wright there is one inescapable historical question, according to Ostling (2003:2) that he insists on, namely: Why did Christianity emerge so rapidly, with such power, and why did believers risk everything to teach that Jesus really rose? The best explanation is that the earliest Christians held two strong convictions that worked in tandem. The first one is that Jesus' tomb was 
discovered empty on Easter morning, and the second is that he appeared to his followers alive in bodily form. The Easter story qualifies thus to be historically true because all proposed alternatives fail to explain the early power of Christianity.

Tom Wright is convinced that the resurrection stories in the Gospels do not say Jesus is raised, therefore we're going to heaven or therefore we're going to be raised. They say Jesus is raised, therefore God's new creation has begun (2006:21). According to him the early Christians did believe that Jesus had been raised bodily from the dead. Wright (1996:29) argues that he cannot make sense of the whole picture, historically or theologically, unless they were telling the truth. It is for Wright (2006:71) inconceivable that worship of Jesus could take place as it did apart from a literal resurrection of Jesus.

That Jesus was raised bodily is for him thus the most likely explanation for the Christian belief. It makes to him the most sense of the data in light of the Second Temple Jewish worldview.

Tom Wright (Ostling 2003:3) dismisses claims that Christian belief echoed the dying-and-rising gods of ancient pagan farmers on grounds that the Jews avoided paganism and that Jesus' resurrection was an one-time occurrence totally unlike the annual, ceremonial rising of gods and corps. Wright argues that the oldest alternative explanation for Jesus' physical resurrection, mentioned in Matthew 28:12-15, was the claim that Jesus' body was stolen from the tomb. Wright notes that the New Testament writers presented that possibility even at the risk of "putting ideas into people's heads" (Ostling 2003:3). They did so, he says, precisely because skeptics were trying to explain why the tomb was empty.

Another standard challenge is that the Easter stories in the four Gospels conflict with one another: Different people arrive at the tomb, they meet different people and Jesus' first appearances are in different locations. Wright turns that inside out. If the accounts were concocted, he said, "you'd expect a better effort to have stories come into line with each other. No, this is the rough sort of way it came out" in the four independent accounts preserved in the Gospels (Ostling 2003:3). By the Gospel accounts, Jesus' resurrected body was like no other. He mysteriously appeared and disappeared (Lk 24:31, 36 and Jn 20:19, 26). Also, his friends did not always recognize him (Lk 24:16, Jn 20:14, 21:4). According to Wright he has been very puzzled how to make sense of these stories. He came to the conclusion that in New Testament portrayal, Jesus rose with a different, glorified body, which is promised to all believers as part of the Easter hope (Ostling 2003:3).

For Wright the Gospels teach a material, physical concept of resurrection. Wright insists that even what Paul meant by "spiritual," was that 
after the resurrection, Jesus' body was "animated by the spirit," "spiritual" does not mean that it is a nonmaterial body. Wright says that Christianity has always believed in life after death and that there would be an undefined period in the presence of God, and that each individual will receive a resurrection body like that of Jesus (Ostling 2003:4).

The question can be asked to Wright: What difference does it make whether resurrection involves material bodies? First, Wright answers: because the church should teach what the first Christians believed. Second, the physical reality of a future world after death shows "the created order matters to God and Jesus' Resurrection is the pilot project for that renewal" (Ostling 2003:4). According to Stewart (2006:73), Wright deems resurrection as historically highly probable, but because he is also a critical realist, he at least emphasizes it as highly probable, not certain.

\section{JOHN DOMINIC CROSSAN}

In the previous paragraph it became clear that Wright is on the historical side of the resurrection-debate line. We'll find Crossan definitely not on that side. $\mathrm{He}$ is on the same side as Patterson. On March, 11, 2005 in the Leavell Chapel on the campus of New Orleans Baptist Theological Seminary in his debate with Wright, Crossan defended the "metaphorical interpretation" side of the resurrection debate-line. Crossan (1994:145) insists in his arguments that 'Jesus' first followers knew almost nothing whatsoever about the details of Jesus' crucifixion, death, or burial. What we have now in those detailed Passion accounts is not history remembered but prophecy historicized". The Passion Narrative, according to Crossan (1991:372) does not relay accurate historical information concerning either Jesus' death or his burial. Their modus operandi was: "Hide the prophecy, tell the narrative, and invent the history."

According to Stewart (2006:74), who recorded the Wright-Crossandebate, one would suspect that given his denial of Jesus' burial, Crossan would also deny Jesus' resurrection. But technically, Crossan does not deny the resurrection. He redefines it. Crossan understands resurrection as a metaphor for Jesus' continued presence in the Church. He insists that the embodied life of Jesus remains powerfully efficacious in this world. Crossan says (1998:xxxi):

Bodily resurrection has nothing to do with a resuscitated body coming out of its tomb. And neither is bodily resurrection just another term for Christian faith itself. Bodily resurrection means that the embodied life and death of the historical Jesus continues to be experienced, by believers, as powerfully efficacious and salvifically 
present in this world. That life continued, as it always had, to form communities of like lives.

On what happened on Easter Sunday, Crossan (1996:121) concludes:

First, the Easter story is not about the events of a single day, but reflects the struggle of Jesus' followers to make sense of both his death and their continuing experience of empowerment by him. Second, stories of the resurrected Jesus appearing to various people are not really about 'visions' at all, but are literary fiction prompted by struggles over leadership in the early Church. Third, resurrection is one - but only one - of the metaphors used to express the sense of Jesus' continuing presence with his followers and friends.

According to Stewart (2006:75) then, the resurrection is for Crossan more hermeneutical than historical. Crossan (2003:29) explains it as follows:

The Christian claim that Jesus was raised bodily from the dead was a startling innovation within Judaism, one indicating that the resurrection had begun - but was going to be a process rather than a single, instantaneous divine action. Such a claim would require evidence that the world was being transformed. Such evidence was found in the Christian community, which was making the world better by its inclusive lifestyle.

At the end of the day, Crossan seems to grant that one may take bodily resurrection either literally or metaphorically, as long as one takes it seriously as general resurrection and apocalyptic consummation already begun - that is, as long as one engages in making the world more just (Stewart 2006:76).

\section{CONCLUSION}

With Stephen Patterson and John Dominic Crossan on the "metaphorical" side of the interpretation debate of the resurrection of Jesus, and Tom Wright on the "historical" side, where does it leave us? Every theologian, in fact every believer has his or her own opinion. When, at the conclusion of this article, I want to make a few comments, I cannot do it objective and scientific. I cannot do biblical criticism without a personal and autobiographical dimension. This is a risk that I am willing to take.

For years, I believed that my faith depends on the historicity of the physical resurrection of Jesus Christ. I confessed unbelievingly as and with the church, the bodily resurrection of all believers at the end of the days until I realized that the texts are not historical documents, but myth. So, I adopted a 
metaphorical interpretation of the resurrection. I understand that the resurrection narratives developed within a mythological worldview. These narratives, as material for preaching in the early congregations emerged around the figure of the historical Jesus. These narratives are mythical in character. The crucial part of these narratives is the Easter narrative, and the essence of the Easter narrative is the part about the resurrection of Christ. For me, the real Easter event was not the resurrection of Christ but the birth of faith. The resurrection is not history, but a myth with an existential message, not a past event of salvation but a present proclamation, which leads to selfunderstanding.

Resurrection faith is thus not the rise of the dead from their tombs. It is about ends and new beginnings. It is about dying for the old, and start living for the new. It is a metaphor for the passage from the death of self-absorption to the life of unselfish love. It is a transition from the darkness of selfish individualism to the light of universal spirit. It is to be free from the slavery of the world to the liberty of the eternal.

For me personally it means that I am free to love God and my neighbour, unselfish, as Jesus preached. And where I sometimes fall short in my love, I can stop being selfish (end) and start loving again (new beginning). Die and resurrect! That is the story of life to me.

There is a parable in the Gospel of Luke that tells the story of the younger one of two brothers who took his share of the estate and squandered his wealth in wild living. When he ends up longing to fill his stomach with the pods that the pigs were eating, he came to his senses and stood up. An ending of a certain way of living, and a new beginning! He died for his old way of living and he stood up (resurrect) to a new life. He experienced death and resurrection. He went back to his father and he found open arms, a new robe, sandals, a ring, and the fattened calf was killed for feasting and celebrating. The kerygma calls it "resurrection". A metaphor that explains the love of God. Every time that I make a new beginning and a fresh start, I experience death of the old and resurrection to the new! I do believe in resurrections!

The narratives, parables and aphorisms of the historical Jesus that caused his rejection and death - re-interpreted by those who were responsible to write the books of the New Testament - have created a world. They have created a world where one, also today, can live simultaneously in this world and in the kingdom of God. In other words, while living in this world, one can live in love! Such a life changes one's whole perspective on life.

When allowing the narratives of Jesus of Nazareth to fuse with the narrative of your own life, you realize that life is about love, and love is about God. That is why I believe that the resurrection is not history, but a myth with an existential 
message. It is not about a historical event, but about living today. Endings and new beginnings. Life and death. Crucifixion and resurrection.

\section{Works consulted}

Borg, M J 1987. Jesus: A new vision: Spirit, culture, and the life of discipleship. San Francisco, CA: HarperSanFrancisco.

Borg, M J \& Wright, N T 1998. The meaning of Jesus: Two visions. San Francisco, CA: HarperSanFrancisco.

Borg, M J 1999. Seeing Jesus: Sources, lenses, and method, in Borg, M J \& Wright, N T, The meaning of Jesus: Two visions, 3-14. San Francisco, CA: HarperSanFrancisco.

Borg, M J 2002. Reading the Bible again for the first time: Taking the Bible seriously but not literally. San Francisco, CA: HarperSanFrancisco.

Crossan, J D 1991. The historical Jesus: The life of a Mediterranean peasant. San Francisco, CA: HarperSanFrancisco.

Crossan, J D 1994. Jesus: A revolutionary bibliography. San Francisco, CA: HarperSanFrancisco.

Crossan, J D 1996. Who is Jesus?: Answers to your questions about the historical Jesus. Louisville, KY: Westminster John Knox.

Crossan, J D 1998. The birth of Christianity: Discovering what happened in the years immediately after the execution of Jesus. San Francisco, CA: HarperSanFrancisco.

Crossan, J D 2003. The resurrection of Jesus in its Jewish context. Neotestamentica 37(1), 28-56.

Ostling, R 2003. Book review: The resurrection of the Son of God by N T Wright, in Courier Post Online, Saturday, April 19, 2003.

Patterson, S J 1998. The God of Jesus: The historical Jesus \& the search for meaning. Harrisburg, PA: Trinity Press International.

Patterson, S J 2004. Beyond the passion: Rethinking the death and life of Jesus. Minneapolis, MN: Fortress.

Stewart, R B (ed) 2006. The resurrection of Jesus: John Dominic Crossan and NT Wright in dialogue. Minneapolis, MN: Fortress.

Wright, N T 1996. How Jesus saw himself. Bible Review 12, 11-32.

Wright, N T 1998. The transforming reality of the bodily resurrection, in Borg, M J \& Wright, N T 1998:111-128.

Wright, N T 2006. The resurrection: Historical event or theological explanation? A dialogue. Opening Statement, in Stewart 2006:16-23. 